\title{
Talking the talk and fitting in: Troubling the practices of speaking 'what you are worth' in Higher Education in the UK
}

\author{
Author A \& Author B
}

\begin{abstract}
In this article we raise questions about fitting in pertaining to various classed identities within two UK Higher Education Institutions. We discuss the pains and privileges attached to accent and ways of speaking worth: Who is able to mobilize and capitalize on inscribed values, as they come to be attached to ways of talking? Accents and ways of talking are part of embodied class identities and whilst some carry connotations of intelligence, other ways of talking are positioned as lacking value, as well as other cultural meanings (Sayer 2002; Spencer, Clegg and Stackhouse 2013; Lawler 1999; Skeggs 1997; Southerton 2002; Taylor 2007; MacFarlane and Stuart-Smith 2012). In this article we discuss our empirical research carried out in two separate qualitative ESRC-funded research projects in the north of England with undergraduate students (Author $B$ ) and university staff (Author A). Focusing primarily on white British ways of talking, we examine how embodying particular accents or ways of talking affect classed notions of 'fitting in' or 'standing out' (Reay, et al 2009: 1; Abraham and Ingram, 2013) in HE. In a climate of uncertainty in Higher Education we are concerned that the importance of demonstrating one's impact, value and worth comes down to more than just productivity, it is becoming demonstrably about being able to 'talk the talk' and we trouble the practices of speaking 'what you are worth'.
\end{abstract}

Keywords: Class, Higher Education, Accent, Language, Value, Gameplaying, Austerity, Worth, Employees, Students

\section{Introduction}

This article draws on the experiences of primarily white British staff and students in Higher Education (HE). We explore debates about fitting in and belonging and we relate this to our own work on ways of 'talking the talk'. These studies provide an insight into how talking a certain way shapes belonging in $\mathrm{HE}$, and how 'talking the talk' is connected to social judgements about class. We discuss what it means for those in Higher Education who are classed because of the way they talk, and we look at the pains and privileges attached to accent and ways of speaking worth in HE. Particular ways of talking, we argue, affect feelings of 'fitting in' or 'standing out' (Reay et al 
2009: 1; Charlesworth 2000; Abraham and Ingram 2013; Taylor 2012). We are concerned that in a climate of uncertainty in Higher Education the importance of demonstrating one's impact, value and worth comes down to more than just productivity, it is becoming demonstrably about being able to talk a classed talk. In this article we trouble the practices of speaking what you are worth (Sayer 2002). Whilst there has been important discussion about how one can make claims to worth (Bradley and Ingram 2012; Sayer 2002; Skeggs 1997; Lawler 1999, 2000, 2005) we are interested specifically in how talking, including accent, local phrases, swearing and slang, is resurfacing as conductors of value in HE. It is important to note from the outset that our findings here relate to primarily white British cultural ways of talking. This is not deliberate, rather this is based on the demographic profile of our sample sets who volunteered to take part in these studies.

Fitting in and standing out through social difference is a subject that Reay et al (2009) have analysed by looking at how the nine working class students they interviewed at elite universities make adaptations to themselves to try and better match the field they find themselves in. Using a Bourdieusian analytical approach, Reay et al, write that usually 'when habitus encounters a field with which it is not familiar, the resulting disjunctures can generate not only change and transformation, but also disquiet, ambivalence, insecurity and uncertainty' (2009: 1105; see also Reay 2005). Abraham and Ingram (2013) also explore student experiences in HE. They looked at how some students felt as though they were missing out on certain experiences at university. Using a Bourdieusian approach, they argue that some students were able to adapt their habitus in a chameleon way to better fit with new fields. Whilst this was not viewed negatively necessarily in their study, we also think it is worth acknowledging that capitalising on one's embodiment to better fit in is not open to everyone and some people will continue to be read negatively, unable to escape being fixed in place despite any efforts. 
We develop these ideas around fitting in and standing out (Reay, et. al, 2009) by looking at cultural inscriptions of language and accent in people's everyday lives. The analysis of cultural knowledge and competencies as expressions of class is emerging in a number of interesting ways, for instance, Bathmaker et al's (2013) study examines how students in a HE institution use knowledge of the prevailing classificatory system to play the game in this setting, put on class performances, and get ahead. They argue that middle class students are able to mobilise cultural capital and aspects of identity perceived to have value more readily than working class students to secure a desirable social position after graduation. This also includes capitalising on parental networks and internships. Students demonstrated knowledge of the game and were familiar with how to play it; the authors state that, "'knowing the game" helps some students maintain social advantage' (Bathmaker et al, 2013: 724). Their aim here is to show that those who know the game and how to play it build on their already valued and accumulated capital to secure a greater advantage over those who are not so familiar with how things are done or how to play the game.

Sayer (2005) discusses how class is an embarrassing subject for many people making it difficult to talk about because it indicates a judgement about a person's moral worth. He writes that, 'Some people may be, or want to be, respectful, considerate and warm to individuals from other classes, but the inequalities themselves are likely to frustrate their attempts by tainting them with suspicions of condescension, disrespect or unwanted familiarity' (2005: 1). According to Sayer (2005), class positions people whether one likes it or not and behaving as though it does not matter, or that one does not think in terms of class, does not make inherent inequalities disappear.

Skeggs (2004a, 2004b) notes how value through class has come to be construed as on the one hand, a matter of precise economic exchange, and on the other, an ambiguous moral notion of 
what is meaningful to certain people. Rather than relying on a quantitative approach that essentially counts value accumulation in units (e.g. money), she develops Bourdieu's notion of exchange. Skeggs argues that a subject with value is evident across a range of spaces, authorising a particular sort of self. For Skeggs (2004a, 2004b), this claim to a valued personhood is undertaken through a continual accumulation and exchange of capitals. She discusses how an arbitrary elevation of certain combinations of capital above others is used to constitute subjects of value. Once these capitals have become legitimated (Lawler, 1999; Skeggs, 1997) they can confer 'social advantage' (Moore, 2008: 102).

Skeggs' model looks at how divisions are drawn between those who can claim value and those who cannot. Those who cannot legitimately attach value to themselves often persist by seeking out new performances, for example through the performance of respectability (Skeggs 1997, 1999, 2011; Sayer 2002a, 2005b, 2005c). She notes that in her previous research, the middle class self sought to acquire capitals via entitlement whilst the working class self sought to defend themselves against social misrecognition (Skeggs 2004a, 2004b). Rather than using a commodity-logic Skeggs turns to another way of generating value, which is overlooked in Bourdieu's typology, through affect. She notes that individuals in her working class women's lives research (1997) found new ways to value themselves and how these individuals used a relational model of generating value. This involved a shared understanding of structural position in a specific space that often went against dominant symbolic relations, and involved sharing emotion. Skeggs (2010) writes that sharing emotions (such as envy, resentment) like this helps individuals to claim value back and make sense of structural inequalities. Further, she notes, 'expressions of value become not just a matter of calculation but understandings of justice, of how class and gender relations enter one's capacity to even engage in exchange' (Skeggs 2010: 33). 
We adopt Skeggs' conceptualisation of value in this research, where she states that value is, '...contingent and situational, circulating through fields (calculation and conversion), and mechanisms (labour, gift, affect) of exchange, carried, inscribed and recognised on bodies', (Skeggs 2010: 34). We are interested then in how talking becomes a mechanism in which value is read off certain people.

\section{Talking the Talk}

Accents and ways of talking are part of embodied class identities; whilst some ways of talking, for instance, via accent, carry connotations of intelligence, other regionalised accents are positioned as lacking value, as well as other cultural meanings (Lawler 1999). Chaney (1994) notes that culture has always been an important topic (see also Geertz 2000) in the social sciences and that the cultural turn is a re-emergence of this as a central theme for understanding peoples' everyday lives and wider society. This cultural direction then in debates about class focuses on the constructed and 'subjective dimensions of classed experience' (Lawler 1999: 4).

The popularity of debates about individualization and the modern reflexive self (Giddens 1991, 1994) have meant that, as Lawler notes, that 'explanations for inequality come to inhere within the subjectivities of persons who are then marked as "wrong" or "right", "deficient" or "acceptable"' (2005a: 798). Lawler suggests (2005: 797 ) that this notion of individualised responsibility occludes 'a system of inequality that is being continually re-made in the large and small-scale processes of social life' and forecloses any challenge to middle classness. Class pervades everyday and domestic lives (Lawler 2005) and as Lawler argues, 'one of the ways in which social class is made "real" is through cultural mechanisms of inclusion and exclusion, of normalization and pathologization (1999: 4-5; see also Lawler 2011). Atkinson suggests that a cultural approach to class has 
meant that 'Empirically it has granted a deeper exploration of the relational sense of identity, difference and similarity articulated by individuals [...] [and] the experiential content of differing positions in the social order' (italics in original, 2010: 44).

These cultural debates, whilst speaking to issues around embodiment and practice, have so far largely passed over how language, and particularly accent, is inscribed with value and recognised as valued or valueless. We explore how something as seemingly arbitrary as an accent, or style of talking, can be loaded with value inscriptions. How does the way we talk, what accent we use, become a measure for intelligence, for example? Class places people (Taylor and Addison 2012) both spatially and culturally, so how we talk matters. Talking the talk is a valuable currency - a vehicle in which value can be made to inhere quite literally in the voices of people. Getting it right and knowing what it is worth across spaces and around different people has its own rewards, whereas getting it wrong, not knowing how people talk around here can be painful and costly at any time, but more this becomes problematic, we want to suggest, in an age of austerity.

Some studies in Sociology connect with how talk is loaded with coded signifiers of value and worth. For instance, Taylor discusses how the women in her qualitative study Fitting into Place?, research about classed and gendered temporalities in the north east, use classing language to account for their feelings and bodily experiences in certain spaces, describing areas and people as 'smelly', 'chav city' and 'posh' (2012: 121). Her study provides an insight into how cultural inscriptions are used by these women to navigate, recognise and resist (such as the 'chav') particular identities of value in their everyday lives. What this shows is that this kind of language places others within a complex classificatory system and acts as a cultural conductor of value.

Spencer et al (2013) have written about the connections between ways of talking spoken by certain adolescents and value 
perceptions of social class in social settings and in secondary schools. What they show is that ways of talking can be used to construct, negotiate and indeed resist a classed identity. This is evidenced in the way some of these adolescents talked about avoiding sounding posh, and others distanced themselves from sounding, as they put it, like a 'chav'. Ways of talking signal class positions to others who are listening. Spencer et al (2013) noted that these adolescents often worked on their talking when conversing with teachers as opposed to peers, negotiating then how they presented their classed selves through talking the (right) talk. This is also echoed in Rampton's (2006) speech study, noted by Spencer et al (2013), where adolescents worked on stylizing their ways of talking according to certain situations, deploying hyper-cockney or hyper-received pronunciation to shape how they were perceived. In MacFarlane and Stuart-Smith's sociolinguistic study (2012) of the Glaswegian accent they talk about how social judgments are attached to different versions of the accent, where some variations are perceived to sound more working class than others. What makes this sociolinguistic study particularly interesting is that they examine the less understood link between language and social perceptions, particularly how this leads to evaluations of worth. MacFarlane and Stuart-Smith (2012) write that these kinds of variation in a specific accent are mapped onto a localized class schema; this is used to socially evaluate the speaker in terms of their class position and valued personhood. Their study then shows a significant and rather concerning relationship between phonetic variations and social judgments. This relationship between ways of talking and class, MacFarlane and Stuart-Smith (2012) suggest, is activated implicitly in interactions. Ways of talking is a mechanism then with which to ascertain a person's social identity, and specifically to place them according to an evaluative class schema.

Whilst MacFarlane and Smith (2012) tracked a relationship between ways of talking and classed judgements by focusing 
specifically on phonetic variations, Rogaly and Taylor's (2009) study includes discussion of how classed judgements pertaining to ways of speaking can be felt under the skin. They discuss two working class women's life histories, one of these women, Lorna, leaves her working class home behind to go to university, and shares how it feels to make these painful adjustments (for instance, to how they talk), and indeed resistances, to make their lives liveable in differently classed spaces. This involved 'social agility', that is, having both the knowledge and capacities to 'present oneself differently to oneself and to various different others' (2009: 52). But being able to present oneself differently through ways of talking, for example, and for that to be authorised as legitimate, requires access to the dominant circuits of value. As Skeggs (2004a) argues, this necessitates having knowledge and resources to produce ideas about one's value. This is not a position available to everyone. Some people are able to use knowledge of this kind of classificatory schema to propertize their personhood (Adkins, 2005, Skeggs, 2004a) whereas some people are positioned as 'beyond appropriation' (Skeggs, 2004a: 26), and beyond the limit of a 'good citizen' (Skeggs and Loveday, 2012: 473). These people are represented, as Skeggs states, as '...the foundational ground of valuelessness from which others can mark and know their distinctions' (2004a: 26).

Accent and ways of talking are utilised as a valued resource. According to Bourdieu (2000: 79) there is a 'linguistic market whenever someone produces an utterance for producers capable of assessing it, evaluating it and settling a price on it....The price that the products of a given competence will receive on a given market depends on the laws of price formation specific to that market'. Bourdieu variously refers to 'linguistic capital' as well as 'linguistic habitus' (2000: 78); the latter allows consideration of the socialised nature of language and accent, however importantly, he situates the value of 'the utterance' as affected by the social space in which it is judged. As Honey says, we have little control over vocal features but 
accent is different in that 'although we do not choose the accent which we grow up speaking, we can alter it to a considerable extent...in relation to the degree of formality or informality of the occasion...[and] in relation to the accent of the person to whom we are speaking' (1989: 57). This may be true in some respects and to certain extents for different people, however what Honey proposes here has distinctly Bourdieusian undertones. The linguistic habitus is a product of social conditions and is the production of utterances adapted to a 'situation' or, rather, adapted to a market or field' (Bourdieu, 2000: 78); this linguistic habitus is itself a capital 'but one which, because it is embodied, appears as innate' (Bourdieu, 2000: 86). However, importantly, it is a capital that has value only insofar as it recognised, or legitimated by the power operating in that field. In $\mathrm{HE}$, Received Pronunciation (RP), for instance, has symbolic prestige; therefore those with similar linguistic habitus will adapt easily; their linguistic habitus is a valued capital in HE. Those whose linguistic habitus does not match the field may thus encounter disjuncture and risk being negatively judged.

The attention to implicit value judgements that are made repeatedly during interactions between people is not new to sociologists. There are numerous studies that show that people do this in different ways (see for example Southerton 2002; Taylor 2007; Walkerdine 1996; Lawler 2005; Skeggs 1997). However, we are concerned that economic cutbacks mean that proving worth is an altogether stickier issue. In such times we are seeing that older mechanisms of classification are being reintroduced (or reemphasised), for instance being able to 'talk the talk'. Those who have access to the dominant classificatory system and control how ideas and markers of class, as well as gender and other identity categories, are given positive or negative values are generally not those people who are most harmed by these practices. Those who can make claims to a valued personhood, by talking the talk, are in receipt of certain advantages, especially in HE (see also Bradley and 
Ingram 2012), such as perceived intelligence, confidence, and respectability. Those who find that they do not talk the (right) talk are fixed as outsiders (thick, parochial, brash), unable to make legitimate claims to belonging in $\mathrm{HE}$.

\section{Methods}

We base our discussions upon data from two research studies. Author A's study is about performances of class and gender in the workplace, and, how emotions are tangled up in game playing at work. She designed a qualitative research study, interviewing employees $(n=31)$ who work in a traditional Higher Education Institution (HEI) based in the north of England. Particular areas of work included estates $(n=12)$, academics $(n=9)$, management $(n=7)$ and business development $(n=3)$. These four areas within the university were identified because they offer the widest scope of workplace performances within a manual, knowledge based and systematic setting. As such, the day-to-day functions of these job roles were not specifically important, rather it was anticipated that employees would have very different experiences interacting with colleagues both within and across these different roles. 19 women were interviewed and 12 men, with ages ranging from 25 to 65 years old. 10 of the sample self-identified as working class, 13 felt that they were middle class and 8 participants did not know how they would describe themselves in class terms. These participants talked about class using their own subjective terms, drawing on varied understandings ranging from what job they did, to what level of education they had attained, their family background, where they lived, what networks they had and what cultural interests they had. This study did not focus expressly on privileges attached to language and ways of talking, nevertheless this was a recurrent theme raised spontaneously by participants in these discussions.

Author B's study is also a qualitative research design where she interviewed undergraduate students $(n=20)$ and carried out 2 focus 
groups - 1 in each of the two HEIs (one 'NEW' - post 1995, and the other 'OLD' - est. 1800s) involved in her study. In Author B's study she focuses on class identity performances in academic and social spaces with undergraduate students. The interview sample consisted of 12 female and 8 male participants and focus group participants included 3 male and 4 female participants. Recruitment involved interested parties completing a 'Participant Profile' that required selfidentifying with a class position along with other information including age, course studied, ethnicity and nationality. Participants were then selected based on their class identification, institution, gender (and availability) in order to get access to a range of views and experiences. Participants also indicated nationality. Although participants had indicated their self-identifications of class, data regarding their home situation, income and living conditions as well as their parental education/occupation was collected and the bases of these self-identifications explored in more detail. With Author B's focus group participants, certain class terms were imposed via the use of vignettes and participants were invited to discuss elements of these short hypothetical profiles/situations. However, the vignettes were constructed using data from four interviewees and therefore using real-life examples to ensure validity and trustworthiness (Mason 2002; Spalding and Phillips 2007), as well as protecting the anonymity of the interviewees. Both studies analyzed data using an iterative approach to produce a thematic coding framework, drawing on qualitative software (Atlas.ti).

Locating ourselves within these two research studies is central to casting attention over what claims we make in this article. Both researchers were frequently recognised and marked during interviews with participants as possessing a working class, northern accent which carried varied value inscriptions. Not all northern accents are working class of course, and not all working class accents are valueless; some people are able to mobilise their accent and the value it is inscribed with to their advantage in certain places and 
around certain people. In this study our own voices will have undoubtedly acted as a coded signifier of value that will have been variously read by participants in different ways depending on their own position within a classed logic. For instance, in Author A's study participants read her as being 'not well read', 'local', and someone who also had to work on her accent to fit in. In both studies, being read in these different ways impacted on how open some participants felt they could be, as well producing interesting slippages in hierarchical positioning between interviewer and participant. We were also sensitive that participants were 'talking the talk' in the interview setting, and that this too involves techniques of telling the self in a particular way (Back 2007; Skeggs 2002). This includes, and is notwithstanding, an ability to narrate a particular kind of self by telling stories that the researchers then expressed an interest in hearing more about.

\section{Why 'talking the talk' matters}

How we talk says a lot about us and what kind of person we wish to be. Talking matters, but why do we think that talking about talking matters here, why now? Watson (2010: 655) describes a move towards a neoliberal marketization of Higher Education Institutions (HEIs) in the UK as 'academic capitalism', with the emphasis being put on 'excellence', 'transparency', 'accountability' and 'impact' but questions who is able to demonstrate them through capacities and image. Both Author A's and Author B's research projects are contextualised within this climate of marketization of HE in the UK. Watson (2010) states that the impetus to cement a strong and valuable image via elite status in these austere times, and beat off the competition, is affecting everyone who works and studies in an educational establishment, from academics and students to cleaners (see also Chapelo 2010; Addison 2012; Taylor 2012).

Similar concerns are echoed by Lynch (2006) who notes that $\mathrm{HE}$ is returning to a divisive climate of elitism. Introducing neoliberal 
values into $\mathrm{HE}$, Watson (2010) suggests, such as excellence and impact, creates an aggressively competitive culture. Whilst the market economy is disguised in politically neutral terms, it 'represents a range of values which confirm and reinforce the established social order of wealth and privileges' (Morley 1997: 234). Much research suggests that middle-class students and variously placed staff must employ strategies to maintain their positions via the acquisition and development of different capitals, qualities and dispositions (Brown 1995; Brown et al. 2002; Addison 2012; Power et al. 2003; Devine 2004; Heath 2007). Brown et al (2002: 6) maintain that large employers are redefining the skills and the personal characteristics of the knowledge workers of the future', which acts to (re)produce social and occupational elites. 'Productive potential' indicators are used by employers, and therefore successful graduates need 'the personality package' to succeed in obtaining these positions (Brown et al, 2002: 28).

The current educational landscape necessitates students and staff (as well as institutions - see Addison 2012; Kitagawa and Lightowler 2013) are entrepreneurial; yet the rules of engagement require playing the game the 'right' way, making the 'right' choices with necessary capital to participate in order to prosper (Mountford 2014). This culture of proving what you are worth, which consolidates divisions between the valued few and supposedly not valued, raises the stakes high where what could be lost are (future) jobs, respect and dignity, but what could be gained for some are prestige, privileges and status. Some employees and students cannot afford to pay the price of this game should they lose so this means that they are deeply invested in the outcome. This imperative to prove worth demands imaginative strategies. We are concerned then that being able to 'talk the talk' increasingly matters.

\section{Talking the talk and making distinctions}


Being able to 'talk the talk' can have a significant return on investment in this game of worth because of how talking and accent is coded with symbolic value by those with the power to legitimate (see also Atkinson 2012). We maintain that in the face of complex changes afoot in the field of HE people are reactivating forms of (embodied) distinctions captured in their own voices. Being able to affect notions of belonging (and insider/outsider status) is a strategy that can help you get ahead in this game of worth. Reading someone's classed position from how they talk is a recurrent theme in both Author A's and Author B's study. In the following excerpts participants talk about forming an impression of another person's classed position based upon accent and ways of talking:

I think language is the biggest thing, you can always tell whether someone has been brought up to know by their language, the way they speak, their parents the way that they have been brought up.

(Lisa, Engineer, 25 years old, unsure of class position)

[AUTHOR A's Study]

You can really tell where someone's from like if they've got a proper strong Geordie accent then you would kind of associate that with working class - but not necessarily, I mean, I guess if you're quite educated then the way you speak and the way you put your words together is quite intelligent then it's sort of middle class as well. And I mean there's a lot of factors as well [...] I think it's quite hard to judge.

(Sophie, 22, Middle-class, NEW University student)

[AUTHOR B's Study]

These excerpts above signal classed connotations of intelligence, wealth and privilege that are associated with particular ways of talking (and middle-classness) and that certain accents were described in interviews (e.g. Geordie - which is a north eastern accent/dialect in the UK) likewise signify a lack (of value in $\mathrm{HE}$ ) but also that these codes are complex and potentially misleading. In this next excerpt Simon's naming of 'Queen's English' refers to RP, which he links with professionalism or middle-classness: 
It's not changing what you know, erm, if you speak with a so called 'Queen's English' that's how all the people who are professional or who are higher up life, that's how they speak, it's almost like that's what you should be like, but it's not really is it?

(Simon, Surveyor, 31 years old, lower middle class)

[AUTHOR A's Study]

RP carries symbolic prestige that is variously (mis)recognised by people. For some, deviating from a more accepted RP accent may encounter disjuncture and risk being negatively judged as outside the boundaries of what they should be like. So, whilst many people who have an RP accent may not recognise its symbolic value, some people who are without this accent are able to see the entitlements it confers. For example, Simon recognises that talking a certain way at work affords him a certain kind of valued reception from others, so in his mind to try and fit in in this social space he has to work on how he talks in these spaces, and this means adjusting his local accent somewhat. This is important in times of austerity as employees turn to more embodied capitals to try and generate value. Whilst some employees may be able to capitalise on valued properties of personhood (e.g. such as deportment and an RP accent) and secure recognition and rewards for their efforts, not everyone is able to do this. Some people cannot escape the stigma that is attached to their own embodied identity, - and accent, even if they were to try. In our own data, working out how to talk the talk is an important way for some participants to protect their position in an increasing marketization of education.

Markers of class are loaded onto accent and language so that how someone talks becomes a way of recognising a person's worth. In Author B's study of students, one of her participants, Craig, documents a sense of certainty of his intellectual ability when he was at his local further education college and associates his accent with his uncertainty at university; despite the fact that 'NEW' University is a local university to him, the cultural value of the way he talks is 
threatened. Here, Craig's accent loses value in relation to others who 'fit' better with university - i.e. those who have an RP accent. It is not to say that his linguistic capital has no cultural value within HE but that it is differently valued intellectually and symbolically within the field. He describes his feelings relationally to other students:

I still feel like these people are clever[er] than us, probably more wealthy - and I don't know... why I think that..... when I'm listening to them other people speak it just [...] well that's [...] so easy to understand and I think I imagine them trying to understand me...now $I^{\prime} m$ so concerned about you know, fully pronunciating $[\ldots] \mathrm{I}$ 'm so conscious about that-that I feel as though I'm kind of - like they can't understand what I'm saying and it does me bloody tits in [...] [I feel] inferior to be honest like when you're in a room with them type of characters like intellectuals - you know what I mean, you're like kind of trying harder but because you're trying so hard you get really nervous and you kind of clam up and everything.

(Craig, 23, Working-class, NEW University student)

[AUTHOR B's Study]

Craig identifies cultural codes aligned with RP as signifying wealth and intelligence, that he, by contrast, sees himself as lacking. His awareness of the differences between his accent and that of others causes a significant amount of distress and it presents additional challenges to him when interacting in seminars where he is not only having to formulate his argument/point, but also constantly monitoring his accent and adapting it to what he deems as more acceptable and easier to understand. Craig's experience of trying to gain (intellectual) value with his peers is one of struggle to adapt the way he speaks to ensure comprehension. The negative effect this has on Craig's perception of himself as a person of intelligence, as a student and as belonging to the student collective/institution is severely fractured - he perceives he doesn't fit and instead stands out as someone who is lacking.

Similar experiences were encountered by other students in Author B's study when discussing their identity within and beyond the gates of the university. For example, Faye also notes how she attempts to 
alter her accent to what she perceives is more acceptable and to avoid being negatively judged (by potential employers and within her peer group):

Yeah I think it is like you know, 'cause I'm in the Law profession and $I^{\prime} m$ doing [armed forces] officer training and [...] it's like expected of you just to be really posh so I always find myself - and like I've been to loads of interviews ... and I'm like trying to so hard to speak, you know, quite poshly - and I've not got a really strong accent anyway but like I find myself like trying really hard but erm like most of the time they can tell I'm from like Manchester (laughs)[...] but I think, you know, but they just assume that you're more [...] I suppose, common in a way and that you're not as well educated and you're poorer as well and I think where I am from, people don't have a strong accent but as you know, people from the centre of Manchester who have like a really strong accent are related to erm scallys.

(Faye, 18, middle-class, OLD University student) [AUTHOR B's Study]

The prospect of job interviews and the performance of a particular accent in this situation was also discussed by Craig, who is aware of his accent being judged negatively (as Faye is too). This suggests that their university experience fractured their sense of self (and the fit of their identity) by way of their accent and its value in different 'markets' both within university but also beyond, having real and lasting consequences.

The associations of 'poor', 'common', and being seen as less educated are the basis of Faye's complex disidentifications with vilified working-classness. Associations of the working-classes as distasteful and lacking in intelligence are part of the mainstay of their vilification against which middle-classness is positioned (Bourdieu 2010). Faye here demonstrates a position of being misinterpreted as working-class; Craig on the other hand identified strongly as working-class. What is at stake here is the ability to deflect negative judgements and relatedly, who is able to fit in or else resist a class schema that attaches negative connotations to a particular accent. Both students find that they must invest in these classed forms of recognition so that they are then able to distance themselves from 
being misrecognised as without worth and improve their chances during job searches.

Yet, also within employment in Higher Education similar issues circulate with ways of talking. Like Faye and Craig, a certain amount of adaptation is required in order to fit. For example, being part of the front line of the university means Jane is required to adjust her own image to fit with being as she puts it 'not posh as such', but something close to it.

At reception environment, certainly if somebody is there or on the phone, you have to be professional because they always say 'you are the front line in the university', so you might be the first contact somebody has with [the] University, so you have to be um, not posh as such [...] With other lasses you can tell [...] they don't have a good education just by the way they speak. How they talk. How they use their words, you can tell how somebody is more educated or not. 'Why aye hinnyi! Ya kna! Gan doon the street' that sort of thing, doesn't mean to say they're not but they're more coarse.

(Jane, Receptionist, 49 years old, working class) [AUTHOR A's Study]

Jane sees herself as being part of a respectable working class and emphasizes her difference to those she sees as being part of a more devalued working class in her discussion. She does this by working on her accent to converge with what she views to be a more middle class version of her own. She is conscious of slippages and how this might be read negatively by others, signifying a lack of fit. She draws a distinction between what is a desirable image in the HEI and what might detract from it by talking about other female co-workers. For her, these women do not get it 'right' and this is apparent in their ways of talking. She reveals a classificatory scheme at work that would position these women as uneducated, abrasive and rough because of how they talk. Jane does not want to risk being coded in this way also since she shares a similar accent to these women. Instead, she works on her voice so that her accent and ways of talking change to fit in with the perceived image she has acquired of 
the organisation. As such, she connects being professional with a performance that would signify middle classness to others. Her discussions highlight that being negatively classed by others in this professionalised setting could impact on one's capacity to fit in and play the game. Every now and then though she does slip in these classed performances, for instance, by calling the researcher 'hinny'. Her linguistic habitus is constantly at risk then of being read in certain ways by others so this means that she is compelled to keep working on the self by 'talking the talk' in certain social spaces at work.

In the following excerpt Linsey recounts how an employee is subjected to much derision by others, which is disguised as humour, because of how he talks during a presentation to colleagues.

\begin{abstract}
Alan, he is still here, he has a very, very, very broad [northern] accent and they used to laugh at him! Behind his back, which is worse of course, he was very able and very good at what he did, but when he presented he wasn't ... on top of that he wasn't very good at presenting... he would always go [...] 'you know', 'you knooow', 'you know?' And people used to laugh at him for that because of the way he spoke [...] But that was a very smug place! It was the [...] Institute and everyone was 'terribly, terribly proper' [...] it is interesting there is this assumption that if you have this posh accent then you should be a lawyer, or a judge, and it comes with it that you are clever.
\end{abstract}

(Linsey, Temporary Lecturer, 51 years old, unsure of class position)

[AUTHOR A's Study]

Linsey's discussions reveal a classificatory scheme at work that is implicitly used by employees to codify and attach value, or not, to certain ways of talking. Linsey's account emphasizes how classed judgements of language and accent can be subtly disguised as being just a bit of harmless fun. Yet, classed codifications like this are far from harmless. Linsey senses how Alan was being humiliated and undermined by his colleagues by these little acts of derision to do with class. Laughing at someone in this way implicitly signals to others that certain ways of talking are 'right', have value, and fit in, whereas talking like Alan is a warning to others of an undesirable 
classed position in this social space. Raisborough and Adams (2008) have examined the role of mockery in the making of white, working class identities in wider cultural and social relations. In particular, they look at how the middle classes are able to mobilise 'disparagement humour' in order to distance and distinguish themselves from a provincial working class 'other'. This kind of humour is outlined as that which 'denigrates, belittles or maligns an individual or social group (Ford and Ferguson, 2004: 79) which Raisborough and Adams argue, shore up the boundaries of normative behaviour through ridicule, shame and embarrassment. Those with the power to legitimate the 'right' way to talk in HE also then preserve these boundaries by marking out ways of talking that do not belong through this disparagement humour. We think this'disparagement activity can be seen in Linsey's account of Alan's treatment by coworkers in the above excerpt.

Raisborough and Adams write that this strategy of ridicule is often a resource available to the middle classes: a group who are, 'more consciously liberal, tolerant, and ironic, and perhaps polite', (Raisborough and Adams 2008: 5.1). They suggest that it is frequently through acts of mockery, which is simply framed as humour and fun, that class distinctions are made and yet subtly unlinked from the middle classes having to account for these practices. This disconnect between caustic, classed humour and responsibility, what Raisborough and Adams characterise as 'lifting' whereby class disgust is disguised as 'only a joke', ensures that the widely accepted perceived liberalism, moral sensitivity and amiability of middle class identities remains intact.

Humour also characterised the ways in which students in Author B's study approached the seemingly awkward topic of class associations with accents. In this instance, Author B used a vignette depicting a student who feels embarrassed because of their strong regional accent when talking in classes and the focus group participants (all of whom identified as middle-class or upper-middle- 
class) were asked to comment on this. The general consensus was that it 'shouldn't be an issue' and interestingly they used humour as a strategy to dismiss any assertion that talking a certain way has a real and painful impact on claims for value:

Erm, I dunno like it's a bit stupid to - it does sound a bit stupid to link social class with [accent] I suppose to an extent, intelligence or you know articulation cos I'm sure lots of erm upper class people are complete idiots, [ALL LAUGH] ...And erm you know, to be fair, and er I think with the accent thing like it seems bit of a silly thing to worry about like everyone sometimes has a bit of banter between them erm, you know [...] it's not something that anyone gets particularly down about but, you know

(Rodd, 21, middle-class, OLD University)

[AUTHOR B's Study]

To claim it is 'stupid' to link accents with intelligence is quite significant. This stands out as quite odd in comparison to the rest of the data (in both Author B and Author A's studies) that identify accent as a marker of social class and education, which poses the question as to why these participants are reluctant to make that connection when everyone else has. None of the focus group participants had a regional accent themselves and spoke with an RP accent, which marks out, as Bourdieu would say, the 'easy relation [to language] of those who are in their element, who have the laws of the market on their side' (1993: 85). Rodd also demonstrates clear framing of (his) middle-classness against an upper class, of whom lots are 'complete idiots', to which the rest of the group acknowledge agreement by joining in with the joke and laughing. Such mockery and 'disparagement humour' (Ford and Ferguson 2004: 79), serves to frame their middle classness, their normality and ordinariness against the exalted upper class. Their concern to fit in is structured around ideals of ordinariness (see Savage et al, 2001; Savage et al, 2005) and part of that relies on what Raisborough and Adams (2008) would perhaps term a 'polite liberalism'; grounding class inequality as an archaic issue to which accent no longer plays a part in such 
times of tolerance and acceptance. For instance, this is exemplified in Eleanor's excerpt below:

I think it's something that maybe people think about and register but they don't hear social class and things in your accent [...] it's just something that you think about for that split second but I think nowadays we've just sort of been brought up to just accept everybody equally so I don't think people still have these issues but ultimately I don't think anyone really judges on that anymore, well I'd like to think so (laughs).

(Eleanor, 22. middle-upper class, OLD University)

[AUTHOR B's Study]

There are contradictions operating in the dialogues of the research participants in that whilst they claim that stigmas attached to accents are 'a thing of the past', they do also recognise how accents serve as ways of making distinctions, revealing a classificatory scheme at work in Higher Education. Eleanor, whilst claiming that people do not judge on accent anymore, also elsewhere mentions how she hopes her public school RP accent has changed. The tendency to see class and the bases on which embodied class differences are perceived as a thing of the past, is part of a tendency to deny the existence of class, which is itself quite a classed thing to say; the tendency to see things marked as negative as belonging in the past is a feature of modernity; that is, a 'conceit of modernity' (Adonis \& Pollard 1997; Lawler, 2005). The students say there are distinctions about how they talk in certain spaces but they refuse to locate them in class.

Other participants in Author A's study however were not so reticent to locate distinctions about talking in class terms. Classed 'performances' can become the subject of scrutiny by others. For example, John directs anger at those in his own workplace who he sees as being frightened of saying and doing the wrong thing and attempt to change themselves through how they talk:

I have seen people of my level $[\ldots]$ talking differently $[. .$.$] they put an$ accent on when they're talking to the consultants, and you look at 
them and you think, hold on, why are you doing that? They try to talk posher, if you like, without any of the accent [...] I've been in the department when the lads are f-ing and blinding between themselves, and then a Consultant will come by and they'll be like [imitates accent] 'Oh yes, sorry, sorry, jah! Oh, how may I help you?' I said to them one time, I said, what the friggen hell are you talking like that for? As soon as somebody walks in the room? 'Well, you know, they're Consultants .. so you have to have a bit of, you know'.

(John, Maintenance Electrician, 53 years old, working class)

[AUTHOR A's Study]

In John's account, these people reveal through their own actions their implicit knowledge of class and how it comes to be mapped on to ways of talking. They invest in a particular kind of classificatory scheme at work in Higher Education to protect their position in social space. Yet it is these kinds of investments in the dominant classificatory scheme that are incomprehensible to John. This is highlighted later when he uses humour to ridicule what he sees as 'pretentious' classed performances enacted by his co-workers. His account highlights how his co-workers try to invest in the game being played by adapting their linguistic habitus' in certain social spaces. Yet John wants to resist working on his own ways of talking despite seeming to know that his position in social space will be coded in a certain way. In particular, his discussions seem to reveal his own disidentifications with the dominant classificatory scheme - this raises an important question about resistance: just how useful is it to resist this class schema, which positions people according to how they talk, when this resistance means for John maintaining a class position that is undesirable in certain social spaces and around certain people (see Lawler 2004, Bourdieu and Wacquant 1990)? Contesting or resisting dominating classification systems in $\mathrm{HE}$, particularly in times of austerity which seem to exacerbate proving your worth, is inherently risky. As Atkinson (2012: 29) notes in his work on everyday classed lives, the economic pressures of finding ways to survive during a difficult time of austerity 'forecloses, for many, the likelihood of resisting' (2012: 29). It is simply too risky for most people to resist 
the dominant ways of playing the game and perhaps this explains why John's co-workers assimilate the codes of the classificatory system into their own ways of talking, rather than seeking to oppose them like John tries to do.

\section{Conclusions}

In this article we wanted to draw attention to both students' and employees' attempts to fit in through practices of 'talking the talk' within two UK Higher Education Institutions. In doing this, we have further developed Reay et al's. (2009: 1) ideas around 'fitting in' and 'standing out' because of certain social differences. We hope that our discussions have revealed some of the pains and privileges that are attached to accent and ways of speaking 'worth', further extending Sayer's (2002) discussions of class and value. We wanted to show that a classificatory system operates to organise and codify language, accent, and ways of talking according to class. In certain social spaces and around certain people talking a certain way can take on, or lose, value. The game that we believe is being played in Higher Education is about knowing how and when to 'talk the talk'. Knowing how talk and accent are codified and laden with value is a vital resource in getting ahead of the pack in times of increased competition. Mobilizing whatever capital is available in order to secure one's social position is not a new concept (Skeggs 1997, Adkins 1995; McDowell, 1997) but what we have suggested here is that, perhaps more than ever, talking matters.

We have highlighted how people are using their accent to protect their social position and further secure an advantage in the field. Our concerns lie with those who are fixed literally in place (Taylor, 2012) by their accents and ways of talking. We feel that more research needs to be undertaken in this area to uncover how the codification of certain ways of talking is still being used to signal (a lack of) intelligence and value in Higher Education, and beyond this social space. We are deeply concerned that in a climate of austerity 
and uncertainty in Higher Education the importance of demonstrating one's impact, value and worth comes down to more than just productivity, it is increasingly about being able to 'talk the talk'. More needs to be done then to trouble the practices of speaking what you are worth. 


\section{References}

ABRAHAM, J. AND INGRAM, N. (2013) 'The Chameleon Habitus: Exploring Local Students' Negotiations of Multiple Fields' in Sociological Research Online, 18(4) 21

ADDISON, M. (2013) 'Knowing you way within and across classed spaces: The $(\mathrm{Re})$ making and (Un)doing of identities of value within Higher Education in the UK' in Y. Taylor (ed.) Educational Diversity: The Subject of Difference and Different Subjects' Houndsmill, Basingstoke, Hampshire Palgrave Macmillan. pp. $236-256$

ADONIS, A. AND POLLARD, S. (1997) A Class Act: The Myth of Britain's Classless Society. London: Hamish Hamilton.

ATKINSON, W. (2010) 'Class, individualization, and late modernity: in search of the reflexive worker', New York, Palgrave Macmillan

BACK, L. (2007) 'The Art of Listening', Oxford, New York: Berg

BATHMAKER, A. M.; INGRAM, N.; and WALLER, R. (2013) 'Higher

Education, social class, and the mobilisation of capitals: recognising playing the game' in British Journal of Sociology of Education 34(5-6): pp. $723-743$

BOURDIEU, P. (1993) The field of cultural production, Cambridge, Polity Press.

BOURDIEU, P. (2000 [1985]) Sociology in Question. London: Sage Publications Ltd

BOURDIEU, P. (2010 [1996]). 'The myth of "globalization" and the European welfare state' in, Sapiro, G. (Ed). Sociology is a Martial Art: Political Writings by Pierre Bourdieu. New York: The New Press.

BouRdieu, P. AND WACQUANT, L. (1992) An Invitation to a Reflexive Sociology Cambridge: Polity Press

BRADLEY, H. AND INGRAM, N. (2012) 'Banking on the future: choices, aspirations and economic hardship in working-class student experience' in W. Atkinson, S, Roberts and M. Savage (eds) Class Inequality in Austerity Britain: Power, Difference and Suffering. Hampshire, Basingstoke: Macmillan, pp. 51-69

BROWN, P. (1995) 'Cultural capital and social exclusion: some observations on recent trends in education, employment and the labour market' in Work, Employment and Society, 9, 29-51.

BROWN, P.; HESKETH, P. AND WILLIAMS, S. (2002) 'Employability in a Knowledge Driven Economy' in Journal of Education and Work, 16 (2): 107126. 
ChAPELO, C. (2010) 'What defines 'successful' university brands?' in International Journal of Public Sector Management', 23(2)

CHARLESWORTH, S. (2000) A phenomenology of working class experience. Cambridge, UK; New York: Cambridge University Press

DEVINE, F. (2004) Class Practices - How Parents Help Children Get Good Jobs, Cambridge: Cambridge University Press.

FORD, T.E. AND FERGUSON, M.A. (2004) 'Social Consequences of Disparagement Humor: A Prejudiced Norm Theory' Personality and Social Psychology Review 8 (1): 79-94.

GEERTZ, C. (2000) The Interpretation of Cultures: Selected Essays, New York: Basic Books

GIDDENS, A (1991) Modernity and self identity: Self and Society in the Late Modern Age Cambridge, Polity,

GIDDENS, A. (1994) 'Risk, trust, reflexivity' in U. Beck, A. Giddens and S. Lash, Reflexive Modernisation: Politics, tradition and aesthetics in the modern social order. Cambridge: Polity

HEATH, S. (2007) 'Widening the gap: pre-university gap years and the 'economy of experience' in British Journal of Sociology of Education, 28 (1): 89-103.

HONEY, J. (1989) Does Accent Matter? The Pygmalion Factor. London; Boston: Faber and Faber.

KITAGAWA, F. AND LIGHTOWLER, C. (2013) 'Knowledge exchange: a comparison of policies, strategies, and funding incentives in English and Scottish higher education' in Educational Research and Evaluation 22 (1): 1-14.

LAWLER, S. (1999) 'Getting Out and Getting Away': Women's Narratives of Class Mobility' in Feminist Review 63(3): 3-24

LAWLER, S. (2000) Mothering the Self: Mothers, Daughters, Subjects London and New York: Polity Press

LAWLER, S. (2004) 'Rules of engagement: Habitus, power and resistance'. In: Adkins L; Skeggs B, (ed.) Feminism After Bourdieu, Oxford: Blackwell: pp.110-128.

LAWLER, S. (2005) 'Disgusted subjects: the making of middle-class identities' in The Sociological Review 53(3): 429-46

LAWLER, S. (2011) "Normal People': Recognition and the Middle Classes" in McLaughlin, J.; Phillimore, P.; and Richardson, D. (eds.) Contesting Recognition: Culture, Identity and Citizenship, Houndsmill, Basingstoke, and Hampshire: Palgrave Macmillan. Pp. 53 - 73 
LYNCH, K. (2006) 'Neo-liberalism and marketisation: the implications for higher education' in European Educational Research Journal, 5(1): pp. 1-17

MacFarlane, A. E. ANd Stuart-Smith, J. (2012) '"One of them sounds sort of Glasgow Uni-ish'. Social Judgements and fine phonetic variation in Glasgow' in Lingua, 122: pp. 764-778.

MAson, J. (2002) Qualitative Researching, London, Thousand Oaks, New Delhi: Sage

MORLEY, L. (1997) 'Change and Equity in Higher Education' British Journal of Sociology of Education. 18 (2): 231-242.

MOUNTFORD, V.G. (2014) 'Rules of engagement beyond the gates: negotiating and capitalising on student 'experience", in Y. Taylor (ed) The Entrepreneurial University: Engaging Publics, Intersecting Impact, London: Palgrave.

NGAI, S. (2007) Ugly Feelings, Harvard: Harvard University Press

POWER, S.; EDWARDS, T.; WHITTY, G. \& WIGFALL, V. (2003) Education and the middle class, Buckingham; Philadelphia: Open University.

RAISBOROUGH, J. AND ADAMS, M. (2008) 'Mockery and morality in popular cultural representations of the white, working class' in Sociological Research Online, 13(6)2: <http://www.socresonline.org.uk/13/6/2.html>

RAMPTON, B. (2006) Language in Late Modernity: Interaction in an Urban School, Cambridge: Cambridge University Press

REAY, D.; CROZIER, G. and CLAYTON, J. (2009) '"Strangers in Paradise"? Working-class Students in Elite Universities' in Sociology, 43(6): pp. 1103-1121

ROGALY, B. AND TAYLOR, B. (2009) '"I don't want to be classed, be we are all classed"'" Making liveable lives across generations' in M. Wetherell (ed.) Identity in the $21^{\text {st }}$ Century: New Trends in Changing Times. Hounsdmill, Basingstoke, Hampshire Palgrave Macmillan

Savage, M.; Bagnall, B.; AND Longhurst, B. (2001) 'Ordinary, Ambivalent and Defensive: Class Identities in the North West of England in Sociology 35(4) 875-892

SAVAGE, M.; BAgnalL, B.; AND LONGHuRst, B (2005) Globalization and Belonging Sage Publications

SAYER, A. (2005a) 'Class, worth, and recognition' in Sociology, 39, pp. 947-63

SAYER, A. (2005b) The moral significance of class, Cambridge: Cambridge University Press 
SAYER, A. (2002) 'What are you worth? Why Class is an Embarrassing Subject', in Sociological Research Online 7(3)

SkEGGS, B. (1997) Formations of Class and Gender: Becoming Respectable. London: Sage.

SKEGGS, B. (1997b) 'Classifying practices: Representations, capitals and recognitions' in P. Mahoney \& C. Zmroczek (eds). Class matters: 'Working class' women's perspectives on social class. London: Taylor and Francis. P.123-139

Skeggs, B. (1999) Matter out of Place: Visibility and Sexualities in Leisure Spaces' in Leisure Studies 18(3)

SKEGGS, B. (2001) 'The toilet paper: Femininity, class and mis-recognition' in Women's Studies International Forum 24(3-4)

SkEGGS, B. (2002) 'Techniques for Telling the Reflexive Self' in T. May (ed.) Qualitative Research in Action, London, Thousand Oaks, New Delhi: Sage. Pp. 349-374

SkegGS, B. (2004a) Class, Self and Cultures. London: Routledge

SKEGGS, B. (2004b) 'Exchange, value and affect: Bourdieu and 'the self' in Adkins, L. and Skeggs, S. (eds) Feminism after Bourdieu Oxford, Blackwell. pp. 75-95

SkEGGS, B. (2005) 'The Making of Class and Gender through visualizing Moral Subject Formation' in Sociology 39(5): pp. 965 - 982

SkEGGS, B. (2010) 'The Value of Relationships: Affective Scenes and Emotional Performances' in Feminist Legal Studies. 18(1): pp. $29-51$

SKEGGS, B. (2011) 'Imagining personhood differently: person value and autonomist working-class value practices', in The Sociological Review, 59(3) pp. 496-513

SKEGGS, B. AND LOVEDAY, V. (2012) 'Struggles for value: value practices, injustices, judgement, affect and the idea of class', in The British Journal of Sociology, 63(3): pp. $472-490$

SOUTHERTON, D. (2002) 'Boundaries of 'Us' and 'Them': Class Mobility and Identification in a New Town' Sociology, 36(1): 171-193

SPALDING, N.J. \& PHILLIPS, T. (2007) 'Exploring the Use of Vignettes: From Validity to Trustworthiness' Qualitative Health Research. 17 (7): 954-962.

SPencer, S.; CLegG, J. ANd StACKhouse, J. (2013) 'Language, social class and education: listening to adolescents' perceptions' in Language and Education, 27:2.pp. 129-143

TAYLOR, Y. (2007) Working-class lesbian life: classed outsiders. Houndsmill, Basingstoke and Hampshire: Palgrave and Macmillan 
TAYLOR, Y. (2008) 'Good Students, bad pupils: Constructions of "aspiration", "disadvantage", and social class in undergraduate-led widening participation work' in Educational Review, 60(2): pp. 155-168

TAYLOR, Y. (2009) 'Facts, fictions, identity constrictions: Sexuality, gender and class in higher education' in Lesbian and Gay Psychological Review, 10(1) Special Issue: pp. 38-47

TAYLOR, Y. (2012) Fitting into Place? Class and Gender Geographies and Temporalities. Surrey: Ashgate

TAYLOR. Y AND AdDISON, M. (2011) 'Placing Research: 'City Publics' and the 'Public Sociologist' Sociological Research Online 6(4)

WALKERDINE, V. (1996) Working class women: psychological and social aspects of survival, in: S. Wilkinson (ed) Feminist social psychologies: International Perspectives, Buckingham: Open University

WATSON, C. (2010) 'Accountability, transparency, redundancy: academic identities in an era of 'excellence" in British Educational Research Journal, First

i 'hinny' denotes a term of endearment in northeastern Geordie dialect. 